\title{
Feasibility and Short-Term Effects of Biphasic Positive Airway Pressure Versus Assist-Control Ventilation in Preterm Lambs
}

\author{
SVEN M. SCHULZKE, GRAEME R. POLGLASE, FOULA SOZO, AND J. JANE PILLOW \\ School of Women's and Infant's Health [S.M.S., G.R.P., J.J.P.], University of Western Australia, Crawley, Western Australia 6009, \\ Australia; Department of Physiology [F.S.], Monash University, Clayton, Victoria 3800, Australia
}

\begin{abstract}
Biphasic positive airway pressure (BiLevel) ventilation allows utilization of two alternating positive end-expiratory pressures (PEEP) while permitting unrestricted spontaneous breathing with superimposed synchronized pressure support. We aimed to compare whether BiLevel versus assist-control (A-C) ventilation provides effective gas exchange and reduces severity of early lung injury in preterm lambs. Preterm lambs delivered at $134 \mathrm{~d}$ (term $=$ $150 \mathrm{~d}$ ) were quasirandomized to BiLevel (PEEP low/high 5/20 cm $\left.\mathrm{H}_{2} \mathrm{O}\right)$ or $\mathrm{A}-\mathrm{C}_{5}\left(\mathrm{PEEP} 5 \mathrm{~cm} \mathrm{H}_{2} \mathrm{O}\right)$ ventilation. Ventilation parameters and arterial blood gases were recorded at regular intervals. Postmortem measurements included pressure-volume relationship, lung inflammatory score, wet/dry body weight ratio, and messenger RNA (mRNA) expression of early markers of lung injury. There were no significant differences between groups in baseline characteristics, oxygenation index $(p=0.49)$, or partial pressure of carbon dioxide $\left(\mathrm{PaCO}_{2}\right)(p=0.08)$. BiLevel group lambs showed improved pressure-volume relationship ( $p=0.006$ ), lower lung inflammatory score $(p=0.013)$, and trend toward lower messenger RNA expression of markers of lung injury compared with $\mathrm{A}-\mathrm{C}_{5}$ group lambs. In unsedated preterm lambs, BiLevel ventilation provides gas exchange equivalent to A-C ventilation and potentially results in reduced lung injury. (Pediatr Res 66: 665-670, 2009)
\end{abstract}

$\mathrm{T}_{1}^{\mathrm{k}}$ There is an increasing awareness of the need for an "open" lung volume approach to mechanical ventilation. Minimal lung injury observed during high-frequency oscillatory ventilation can be reproduced using conventional ventilation strategies that optimize positive end-expiratory pressure (PEEP) (1). This approach has not gained widespread clinical support in neonates because of concerns about the potential of persistently raised PEEP levels (PEEP $10 \mathrm{~cm} \mathrm{H}_{2} \mathrm{O}$ ) to impede venous return, decrease cardiac preload, and pulmonary blood flow and impair cerebral blood flow $(2,3)$.

An alternative approach is offered by BiLevel ventilation [also known as biphasic positive airway pressure (BIPAP or $\mathrm{PeV}+)$ ]. BiLevel offers a flexible mode of ventilation similar to assist-control (A-C) except that it cycles between a low and a high level of positive pressure or PEEP $\left(\mathrm{PEEP}_{\mathrm{L}}\right.$ and $\left.\mathrm{PEEP}_{\mathrm{H}}\right)$. Transitions between levels of PEEP can be triggered by the

Received April 21, 2009; accepted August 11, 2009.

Correspondence: Sven Schulzke, MD, FRACP, King Edward Memorial Hospital for Women, 374 Bagot Road, Subiaco, Western Australia 6008, Australia; e-mail: sven.schulzke@health.wa.gov.au

Supported by a career development award (404102) from the National Health and Medical Research Council (Australia) (J.J.P.) and the Women and Infants Research Foundation (J.J.P.). Support was also obtained from Nellcor Puritan Bennett and Tyco Healthcare, Australia in the form of ventilator loans and a small donation to the Women and Infants Research Foundation. patient (synchronized transitions) or initiated by the ventilator according to preset time $\left(t_{\mathrm{L}}\right.$ or $\left.t_{\mathrm{H}}\right)$ on each level of PEEP (time-based transitions). Spontaneous breathing is achievable at either PEEP level, and these breaths can be pressure supported. It is possible that cycling PEEP between low and high levels may offer the opportunity to recruit additional lung volume by exploiting the nonlinear dynamic nature of the pressure-volume relationship, while providing some "relief" from the effects of persistently raised background PEEP on cardiovascular status.

Superior gas exchange and cardiovascular function with BiLevel ventilation were demonstrated in adult animal models of acute lung injury comparing BiLevel with pressure support ventilation (4) and in clinical trials of BiLevel versus volumecontrolled ventilation in adults with acute respiratory distress syndrome (ARDS) $(5,6)$. A reduced need for sedation and decreased time on the ventilator in BiLevel compared with A-C was shown in a large cohort study in adults recovering from cardiac surgery (7). BiLevel ventilation is being used increasingly as an alternative ventilation strategy to conventional ventilation in ARDS (8), and its use was found to be safe in infants beyond the newborn period (9). Nonsynchronized nasal biphasic pressure ventilation was reported to improve gas exchange compared with nasal continuous positive airway pressure (CPAP) in stable preterm infants recovering from respiratory distress syndrome (RDS) (10). Endotracheal BiLevel ventilation has not been assessed in preterm neonates with acute RDS.

The objective of this study was to compare BiLevel ventilation with $\mathrm{A}-\mathrm{C}$ ventilation in a preterm lamb model of neonatal lung disease. We investigated gas exchange and early indicators of lung injury. We compared BiLevel ventilation using $\mathrm{PEEP}_{\mathrm{L}}$ of $5 \mathrm{~cm} \mathrm{H} \mathrm{H}_{2} \mathrm{O}$ and $\mathrm{PEEP}_{\mathrm{H}}$ of $20 \mathrm{~cm} \mathrm{H}_{2} \mathrm{O}$ with A-C ventilation with PEEP $5 \mathrm{~cm} \mathrm{H}_{2} \mathrm{O}$. We hypothesized that the use of an intermittent high PEEP in BiLevel ventilation would reduce lung injury compared with A-C ventilation while maintaining adequate gas exchange. Some of the results of this study were reported previously in abstract form (Schulzke SM

Abbreviations: A-C, assist-control; BiLevel, biphasic positive airway pressure; CTGF, connective tissue growth factor; CYR61, cysteine-rich protein 61; EGR1, early growth response one; MAP, mean airway pressure; OI, oxygenation index; PEEP, positive end-expiratory pressure; PIP, peak inspiratory pressure; PS, pressure support; RR, respiratory rate; $\boldsymbol{t}_{\mathrm{H}}$, time on high PEEP; $\boldsymbol{t}_{\mathrm{L}}$, time on low PEEP; UVC, unventilated control; $\boldsymbol{V}_{\mathrm{T}}$, tidal volume 
et al., Biphasic (Bilevel) versus assist-control ventilation in preterm lambs, 2007 ERS Annual Meeting, September 15-19, 2007, Stockholm, Sweden, Abstract P2338).

\section{MATERIALS AND METHODS}

Ethics. The investigations were approved by the Animal Ethics Committee of the Department of Agriculture and Food, Western Australia.

Animals, delivery, and postnatal care. We used an established ovine model of lung disease in moderately preterm lambs (11). Twenty-one lambs were delivered by caesarean section at $134 \mathrm{~d}$ gestation (term $=146 \mathrm{~d}$ ) to date-mated Merino ewes. One lamb died at delivery. Remaining lambs were weighed, dried, intubated with a $4.5-\mathrm{mm}$ internal diameter cuffed endotracheal tube, and quasirandomized to an unventilated control group $(\mathrm{UVC}, n=6)$ that was euthanized immediately before delivery by $50 \mathrm{mg} / \mathrm{kg}$ i.v. pentobarbitone (Abbott Laboratories, Sydney, Australia) or to one of two ventilation groups using a Puritan Bennett 840 ventilator (Nellcor Puritan Bennett, Pleasanton, CA): 1) BiLevel ventilation using a PEEP $\mathrm{P}_{\mathrm{L}}$ of $5 \mathrm{~cm} \mathrm{H}_{2} \mathrm{O}$, a PEEP $\mathrm{P}_{\mathrm{H}}$ of $20 \mathrm{~cm}$ $\mathrm{H}_{2} \mathrm{O}$, and pressure support of $25 \mathrm{~cm} \mathrm{H}_{2} \mathrm{O}$ (BiLevel, $n=7$ ); 2) A-C with PEEP of $5 \mathrm{~cm} \mathrm{H}_{2} \mathrm{O}$ and peak inspiratory pressure (PIP) of $30 \mathrm{~cm} \mathrm{H}_{2} \mathrm{O}\left(\mathrm{A}-\mathrm{C}_{5}, n=\right.$ 7). The baseline ventilator settings for the first $10 \mathrm{~min}$ after delivery are defined in Table 1. Both BiLevel and $\mathrm{A}-\mathrm{C}_{5}$ groups were ventilated using a pressure-controlled, volume-targeted, flow-triggered (sensitivity $0.2 \mathrm{~L} / \mathrm{min}$ ) ventilation strategy, i.e., the initial PIP of $30 \mathrm{~cm} \mathrm{H}_{2} \mathrm{O}$ (equivalent to $\mathrm{PEEP}_{\mathrm{L}}+$ pressure support in BiLevel group) in each group was subsequently adjusted to achieve tidal volumes $\left(V_{\mathrm{T}}\right)$ of $7-8 \mathrm{~mL} / \mathrm{kg}$. $V_{\mathrm{T}}$ estimation and pressure adjustment in lambs ventilated with BiLevel were based on readings obtained on $\mathrm{PEEP}_{\mathrm{L}}$. An example of differences in the pressure wave form between the ventilation modes is shown in Figure 1. All ventilated lambs had a set (backup) respiratory rate (RR) of 20 breaths/min and a fixed fractional inspired oxygen concentration $\left(\mathrm{FiO}_{2}\right)$ of 0.4. In BiLevel mode, the ventilator cycled between the two preset levels of PEEP $\left(\mathrm{PEEP}_{\mathrm{L}}\right.$ and $\left.\mathrm{PEEP}_{\mathrm{H}}\right)$ based on preset time on $\operatorname{PEEP}_{\mathrm{L}}\left(t_{\mathrm{L}}, 2.0 \mathrm{~s}\right)$ and $\operatorname{PEEP}_{\mathrm{H}}\left(t_{\mathrm{H}}, 1.0 \mathrm{~s}\right)$ while delivering pressure support for spontaneous breathing throughout the ventilatory cycle. In A-C mode, the ventilator allowed for time-limited (inspiratory time $0.5 \mathrm{~s}$ ) spontaneous inspirations and all spontaneous respiratory efforts were supported with the preset PIP. Lambs were not sedated to facilitate spontaneous breathing effort. After intubation and commencing ventilation, the lambs were positioned prone, covered with transparent occlusive wrap (NeoWrap; Fisher \& Paykel Healthcare, Auckland, NZ), and kept warm on an infant radiant warmer (CosyCot; Fisher \& Paykel Healthcare).

Lung processing. Ventilated lambs were euthanized $(50 \mathrm{mg} / \mathrm{kg}$ pentobarbitone) at $120 \mathrm{~min}$, and the tracheal tube was clamped for $3 \mathrm{~min}$ to facilitate oxygen absorption and lung collapse for subsequent determination of the pressure-volume relationship (12). Lambs were weighed to obtain dry weight; lungs were weighed, pressure-volume relationship was determined from excised lungs (including UVC group), and samples from the right lower lobe were taken for molecular analyses.

Time course of physiologic variables. Variables measured by the ventilator's built-in hot-film anemometer and manometer $\left[V_{\mathrm{T}}\right.$ and minute volume, total RR, PIP, and mean airway pressure (MAP)], arterial $\mathrm{pH}$, partial pressure of arterial oxygen $\left(\mathrm{PaO}_{2}\right)$, and carbon dioxide $\left(\mathrm{PaCO}_{2}\right)$ were documented at 10 , $20,30,45,60,90$, and 120 min postdelivery. Blood from an umbilical arterial catheter was used for blood gas and $\mathrm{pH}$ measurements (ABL 800, Radiometer, Copenhagen, Denmark). Oxygenation index (OI) was calculated as: $\mathrm{OI}=$ $\mathrm{MAP} \times \mathrm{FiO}_{2} \times 100 / \mathrm{PaO}_{2}(13)$.

Histologic inflammation score. The right upper lobe of each lung was inflation fixed with $10 \%$ formalin at $30 \mathrm{~cm} \mathrm{H}_{2} \mathrm{O}$ pressure. Lobes were cut into 5- $\mu \mathrm{m}$ serial sections, and three hematoxylin and eosin-stained sections were selected randomly in a blinded fashion by one observer (G.R.P.). The amount of inflammation in UVC, BiLevel, and $\mathrm{A}^{-\mathrm{C}_{5}}$ lambs was graded using a score validated previously in this ventilated preterm lamb model (14). Each lung

Table 1. Initial ventilator settings

\begin{tabular}{lcccccc}
\hline & $\begin{array}{c}\text { Backup rate } \\
\text { (breaths/min) }\end{array}$ & $\begin{array}{c}\text { PIP } \\
\left(\mathrm{cm} \mathrm{H}_{2} \mathrm{O}\right)\end{array}$ & $t_{\mathrm{I}}(\mathrm{s})$ & $\begin{array}{c}\text { PEEP } \\
\left(\mathrm{cm} \mathrm{H}_{2} \mathrm{O}\right)\end{array}$ & $t_{\text {PEEP }}(\mathrm{s})$ & $\begin{array}{c}\text { PS } \\
\left(\mathrm{cm} \mathrm{H}_{2} \mathrm{O}\right)\end{array}$ \\
\hline BiLevel & 20 & $(30)^{*}$ & $0.5 \dagger$ & $\begin{array}{c}5 \text { (low) } \\
2\end{array}$ & 2 (low) & 25 \\
${\mathrm{~A}-\mathrm{C}_{5}}^{20}$ & 20 & 30 & 0.5 & 5 & - & - \\
\hline
\end{tabular}

* Peak pressure achieved with PS breaths at either low or high PEEP.

$\dagger$ Mandatory breaths only (spontaneous breaths flow cycled).

PS, pressure support; $t_{\text {PEEP }}$, time cycled at PEEP level.
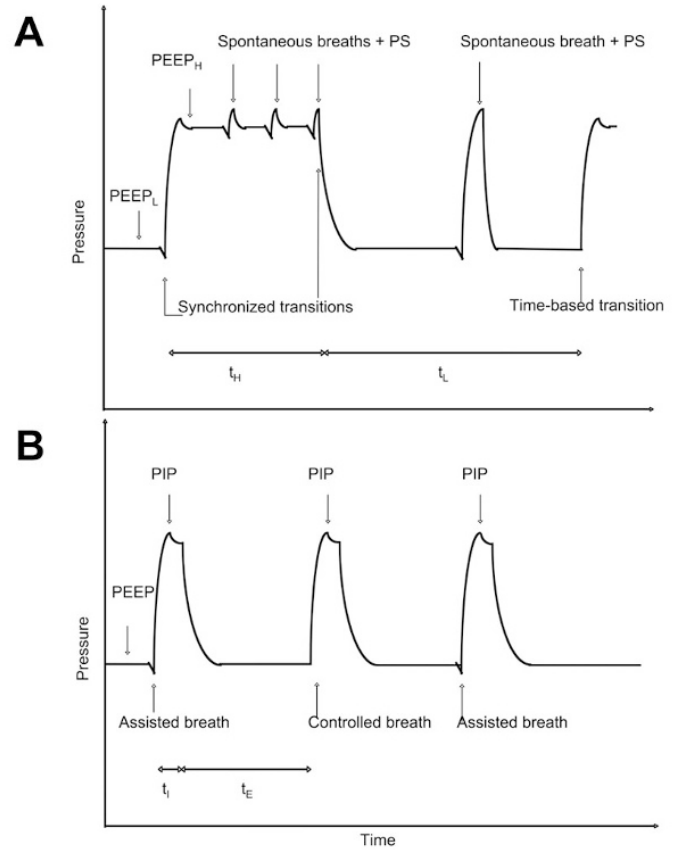

Figure 1. Characteristics of BiLevel $(A) v s$ assist-control $(B)$ ventilation. In BiLevel mode, the ventilator cycles between two preset levels of PEEP: PEEP $_{\mathrm{L}}$ and $\mathrm{PEEP}_{\mathrm{H}}$. Transitions between levels of PEEP can be flow triggered by the patient (synchronized transitions) or initiated by the ventilator according to preset time on each level of PEEP (time-based transitions). Flowtriggered spontaneous breathing with pressure support is achievable on either level of PEEP. In A-C mode, the ventilator applies breaths that are pressure controlled and time cycled with preset PEEP, PIP, and $t_{\mathrm{I}}$. Flow-triggered spontaneous inspirations are achievable on PEEP but not PIP level. All spontaneous breaths are assisted. PEEP $_{\mathrm{L}}$, low level of PEEP; $\mathrm{PEEP}_{\mathrm{H}}$, high level of PEEP; $t_{\mathrm{L}}$, time on $\mathrm{PEEP}_{\mathrm{L}} ; t_{\mathrm{H}}$, time on $\mathrm{PEEP}_{\mathrm{H}} ; t_{\mathrm{I}}$, inspiratory time; $t_{\mathrm{E}}$, expiratory time.

section was scored as 0 (no inflammatory cells in tissue or airspaces), 1 (a few cells), 2 (a moderate cell infiltration), and 3 (large numbers of inflammatory cells in airspaces and tissue), assuming a linear relationship between amount of inflammation and inflammatory score (14). Average scores for airspaces and tissue were calculated for each animal (15).

Messenger RNA (mRNA) extraction and quantitative PCR. Messenger RNA (mRNA) expression of early markers of neonatal lung injury (16), including early growth response one (EGRl) (17), cysteine-rich protein 61 (CYR61) $(18,19)$, and connective tissue growth factor $(C T G F)(20,21)$, was measured using quantitative PCR (qPCR). RNA was extracted from the lung tissue (Qiagen RNeasy Mini Kit; Qiagen, Valencia, CA) and reverse transcribed into complementary DNA (cDNA) (M-MLV Reverse Transcriptase, RNase H Minus, Point Mutant Kit; Promega, Madison, WI). qPCR was performed using a Realplex Real-Time Multiplexing System (Eppendorf, Hamburg, Germany). The qPCR reaction conditions and primers for these genes were published previously (16). The mRNA levels of each gene for each animal were normalized using the $\Delta \Delta \mathrm{C}_{\mathrm{t}}$ (cycle threshold) method. The mean mRNA level for each gene in control animals was set to 1 and the mean mRNA levels for each ventilation modality were expressed relative to the mean value in control animals.

Data analysis and statistics. Results are shown as mean (SEM) unless specified otherwise. Statistics were analyzed using Stata v10.0 (Stata Corporation, College Station, TX) and Prism v5.0 (Graphpad Inc, San Diego, CA). One-way ANOVA with (inflammation score) and without (pressure-volume relationships, biochemical markers) repeated measures and Bonferroni's multiple comparison test were used for statistical comparisons of continuous variables, with treatment modality as the independent factor. Categorical data were analyzed using Fisher's exact test. Two-tailed paired (time course of physiologic variables) and unpaired (wet/dry weight ratios) $t$ tests were used to compare outcomes that were only available in BiLevel and $\mathrm{A}-\mathrm{C}_{5}$ groups. Statistical significance was accepted as $p<0.05$. 
Table 2. Baseline variables

\begin{tabular}{lcccc}
\hline & UVC & BiLevel & A-C ${ }_{5}$ & $p$ \\
\hline Number & 6 & 7 & 7 & - \\
Male $(n)$ & 5 & 2 & 1 & 0.054 \\
Body weight $(\mathrm{kg})$ & $3.54(0.22)$ & $3.58(0.15)$ & $3.73(0.11)$ & 0.91 \\
Cord blood $\mathrm{pH}$ & - & $7.26(0.02)$ & $7.28(0.02)$ & 0.50 \\
\hline
\end{tabular}

Data presented as mean (SEM).

Table 3. Impact of ventilation modality on physiological variables

\begin{tabular}{lccl}
\hline & \multicolumn{2}{c}{ Ventilation modality } & \\
\cline { 2 - 3 } \multicolumn{1}{c}{ Variable } & BiLevel $(n=7)$ & $\mathrm{A}-\mathrm{C}_{5}(n=7)$ & \multicolumn{1}{c}{$p$} \\
\hline MAP $\left(\mathrm{cm} \mathrm{H}_{2} \mathrm{O}\right)$ & $13.9(0.43)$ & $13.0(0.23)$ & 0.014 \\
Oxygenation index & $6.25(0.27)$ & $5.73(0.41)$ & 0.49 \\
$V_{\mathrm{T}}\left(\mathrm{mL} \cdot \mathrm{kg}^{-1}\right)$ & $7.7(0.27)$ & $7.4(0.11)$ & 0.35 \\
$\mathrm{RR}\left(\mathrm{min}^{-1}\right)$ & $56.5(1.76)$ & $46.9(1.44)$ & 0.005 \\
$\mathrm{MV}\left(\mathrm{L} \cdot \mathrm{kg}^{-1} \cdot \mathrm{min}^{-1}\right)$ & $0.31(0.01)$ & $0.36(0.01)$ & 0.007 \\
$\mathrm{PIP}\left(\mathrm{cm} \mathrm{H}_{2} \mathrm{O}\right)$ & $22.9(1.63)$ & $23.9(1.22)$ & 0.12 \\
$\mathrm{PaO}_{2}, 0-60 \mathrm{~min}$ & $95.1(2.36)$ & $126.2(8.12)$ & 0.018 \\
$\quad(\mathrm{~mm} \mathrm{Hg})$ & & & \\
$\mathrm{PaO}_{2}, 61-120 \mathrm{~min}$ & $86.7(0.59)$ & $101.5(7.71)$ & 0.20 \\
$\quad(\mathrm{~mm} \mathrm{Hg})$ & & & \\
$\mathrm{pH}$ & $7.31(0.02)$ & $7.31(0.02)$ & 0.97 \\
$\mathrm{PaCO}_{2}(\mathrm{~mm} \mathrm{Hg})$ & $50.8(2.10)$ & $47.5(1.90)$ & 0.08 \\
\hline
\end{tabular}

Data presented as mean (SEM). Values of ventilator displayed variables and blood gases reflect mean values of repeated measures during $2 \mathrm{~h}$ of ventilation unless specified otherwise.

$\mathrm{MV}$, mechanical ventilation.

\section{RESULTS}

Table 2 summarizes baseline values for UVC, BiLevel, and A- $\mathrm{C}_{5}$ groups. There was a trend toward a higher proportion of male lambs in the UVC group $(p=0.054)$. Body weight and cord $\mathrm{pH}$ were not different between the groups.

Time course of physiologic variables. Table 3 highlights differences in ventilatory variables and blood gases between BiLevel and $\mathrm{A}-\mathrm{C}_{5}$ groups. Further details on the time course of physiologic variables are given in Figure 2. BiLevel lambs had higher MAP than $\mathrm{A}-\mathrm{C}_{5}$ lambs (mean difference $0.9 \mathrm{~cm}$ $\mathrm{H}_{2} \mathrm{O}, p=0.014$ ). Respiratory rate in the BiLevel lambs was higher (mean difference $9.6 \mathrm{~min}^{-1}, p=0.005$ ) and minute ventilation lower than in $\mathrm{A}_{-} \mathrm{C}_{5}$ lambs (mean difference -0.05 $\left.\mathrm{L} \cdot \mathrm{kg}^{-1} \cdot \min ^{-1}, p=0.007\right) . \mathrm{PaO}_{2}$ in BiLevel lambs was lower than in $\mathrm{A}-\mathrm{C}_{5}$ lambs during the first 60 min (mean difference $-31.1 \mathrm{~mm} \mathrm{Hg}, p=0.018$ ) but not different between groups after $60 \mathrm{~min}$ (mean difference $-17.8 \mathrm{~mm} \mathrm{Hg}, p=0.20$ ). There were no differences between groups in OI, $V_{\mathrm{T}}, \mathrm{PIP}, \mathrm{Paco}_{2}$, or $\mathrm{pH}$.

Pressure-volume relationship, wet/dry weight ratio, and inflammation score. BiLevel lambs had a higher static compliance than both $\mathrm{A}-\mathrm{C}_{5}$ lambs $(p=0.006)$ and UVC lambs $(p<0.001)$ (Fig. 3). There was no difference in wet/dry weight ratio between BiLevel and $\mathrm{A}-\mathrm{C}_{5}$ lambs $(p=0.77)$. BiLevel lambs had lower inflammatory scores in lung tissue than A-C $\mathrm{C}_{5}(p=0.013)$ but not UVC lambs ( $\left.p=0.35\right)$ (Fig. 4).

mRNA expression of EGR1, CYR61, and CTGF. Figure 5 illustrates differences in mRNA expression of EGRl, $C Y R 61$, and $C T G F$. There was no difference in mRNA levels of EGRI ( $p=0.42)$, CYR61 ( $p=0.23)$, and CTGF ( $p=0.18)$ between BiLevel and $\mathrm{A}-\mathrm{C}_{5}$ groups. BiLevel lambs had higher
mRNA levels of EGRI than UVC lambs $(p=0.006)$, but there was no difference in mRNA levels of CYR61 $(p=0.01)$ and CTGF $(p=0.04)$ between BiLevel and UVC lambs (adjusted $p$ value indicating significance of multiple comparisons: $p=0.008) . \mathrm{A}^{-C_{5}}$ lambs had higher $E G R I(p=0.004)$, CYR61 $(p=0.001)$, and CTGF $(p=0.007)$ mRNA levels compared with UVC lambs.

\section{DISCUSSION}

Summary of main findings. We found that BiLevel ventilation in preterm lambs is feasible and provides gas exchange comparable with $\mathrm{A}-\mathrm{C}_{5}$ ventilation immediately postdelivery. BiLevel ventilation may reduce acute lung injury compared with $\mathrm{A}-\mathrm{C}_{5}$ ventilation, as demonstrated by improved pressurevolume relationship, lower lung tissue inflammatory scores compared with $\mathrm{A}-\mathrm{C}_{5}$ group lambs, and CYR61 and CTGF mRNA levels of $A-C_{5}$ but not BiLevel lambs being higher than those of UVC lambs.

Gas exchange. Ventilation modality did not significantly influence $\mathrm{OI}$ and $\mathrm{PaCO}_{2}$, suggesting that arterial oxygenation and elimination of $\mathrm{CO}_{2}$ in BiLevel and A-C groups were similar. BiLevel lambs had slightly higher MAP than A-C $\mathrm{C}_{5}$ lambs (mean difference $0.9 \mathrm{~cm} \mathrm{H}_{2} \mathrm{O}$ ). The increase in MAP in BiLevel lambs was lower than expected because of the rapid decrease in pressure support as ventilation was weaned to target the predefined $\mathrm{PaCO}_{2}$ range and $V_{\mathrm{T}}$ of $7-8 \mathrm{~mL} / \mathrm{kg}$. Consequently, the small increase in MAP was restricted to the first $30 \mathrm{~min}$ of the study period. The clinical importance of this small difference in MAP is questionable because in a clinical setting, $\mathrm{FiO}_{2}$ and/or PIP would be adjusted to maintain $\mathrm{PaO}_{2}$ within target range and the accuracy of built-in manometers is limited (22). It is likely, therefore, that any differences in outcomes between the BiLevel and $\mathrm{A}-\mathrm{C}_{5}$ groups are primarily related to PEEP strategy, rather than MAP per se.

A more intriguing finding is the difference in the time course of $\mathrm{PaO}_{2}$ between BiLevel and $\mathrm{A}-\mathrm{C}_{5}$ group animals. After commencement of mechanical ventilation and postnatal adaptation, $\mathrm{PaO}_{2}$ in BiLevel lambs showed little change over time, whereas $\mathrm{PaO}_{2}$ in $\mathrm{A}-\mathrm{C}_{5}$ lambs increased rapidly after delivery followed by a decline after $30 \mathrm{~min}$, i.e., $\mathrm{PaO}_{2}$ in BiLevel lambs was lower than in $\mathrm{A}-\mathrm{C}_{5}$ lambs during the first $60 \mathrm{~min}$ of ventilation. Previous studies in an adult pig model $(23,24)$ and human adults $(25-27)$ indicated arterial oxygenation in BiLevel ventilation to be at least equivalent to A-C and pressure support ventilation. Given that the use of periods of high PEEP arguably increases lung recruitment (28), the lower initial $\mathrm{PaO}_{2}$ in BiLevel lambs compared with the A-C group may have resulted from reduced pulmonary blood flow caused by high $\operatorname{PEEP}_{\mathrm{H}}$ (29), transiently offsetting the benefits of PEEP for lung recruitment. Confirmation of this hypothesis requires measurement of lung volume and hemodynamics in future studies. The lack of measurement of hemodynamics in this study precludes any conclusions regarding the impact of ventilation modality on cardiac function.

Influence of ventilation modality on lung injury. As expected, pressure-volume relationship in both BiLevel and A- $\mathrm{C}_{5}$ groups demonstrated higher static compliance compared 

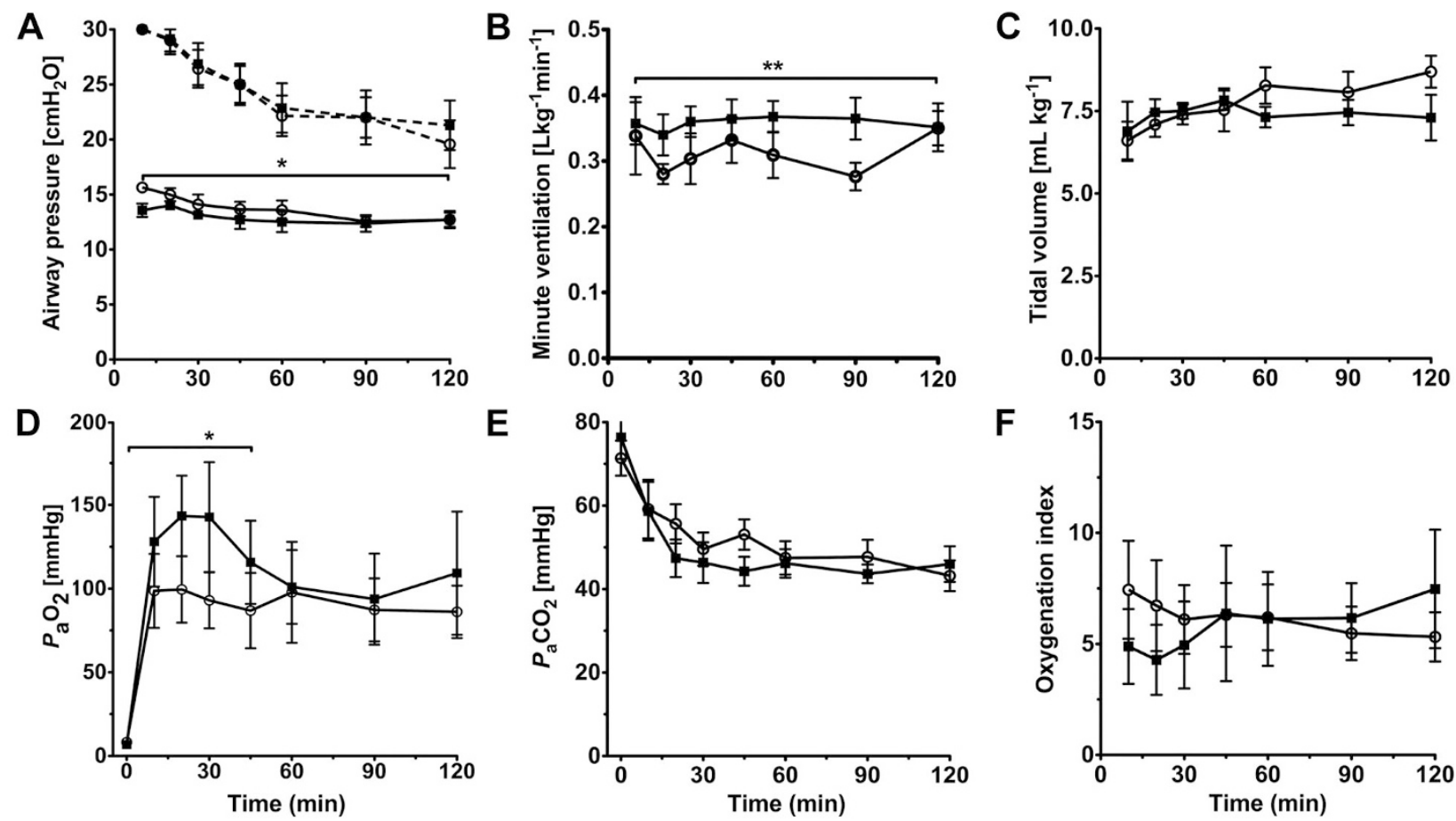

Figure 2. Time course of changes in physiologic variables and blood gases: A, mean airway pressure (continuous lines) and peak airway pressure (dashed lines), $B$, minute ventilation, $C$, tidal volume, $D, \mathrm{PaO}_{2}, E, \mathrm{PaCO}_{2}$, and $F$, oxygenation index. Circles, BiLevel; squares, A-C ${ }_{5} \cdot{ }^{*} p<0.05 ; * * p<0.01$.

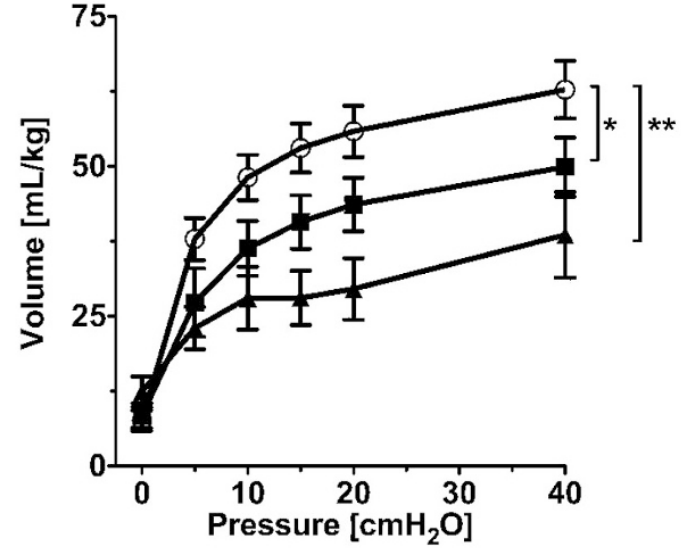

Figure 3. Pressure-volume relationship. The deflation limb of the static pressure-volume relationship obtained postmortem in BiLevel, A- $\mathrm{C}_{5}$ and UVC lambs. There were differences among the BiLevel $(\bigcirc), A-C_{5}(\square)$, and UVC $(\boldsymbol{\Delta})$ groups with BiLevel lambs having higher static compliance than both $\mathrm{A}-\mathrm{C}_{5}$ and UVC lambs. *p $<0.05 ; * p<0.01$.

with UVC lambs because of poor lung aeration in the latter. The improved pressure-volume relationship and decreased histologic lung inflammation score in BiLevel versus $\mathrm{A}_{-} \mathrm{C}_{5}$ ventilation, and the trend toward lower mRNA levels of CYR61 and CTGF in BiLevel lambs highlights the relevance of ventilation modality on lung injury. Three major suspected risk factors of ventilator-induced lung injury in surfactantdepleted newborn lungs are overdistension by large tidal volumes (30), repetitive opening and closing of alveolar units because of low PEEP ventilation strategy (31), and oxygen toxicity (32). A few large breaths during resuscitation initiated lung injury in preterm lambs (33), even when used in combi-

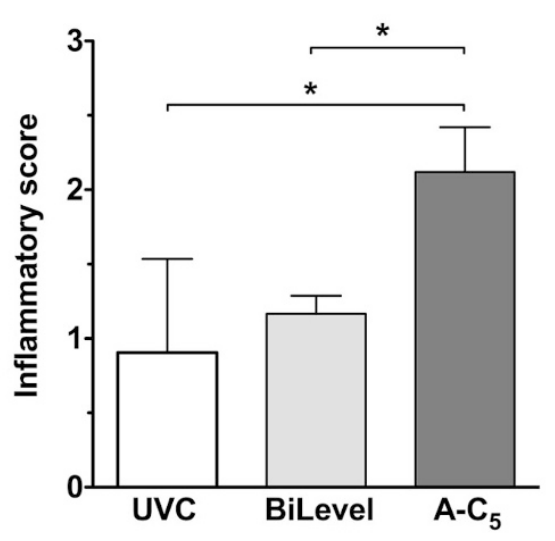

Figure 4. Average inflammatory scores in lung tissue. BiLevel lambs had lower inflammatory scores than A-C $\mathrm{C}_{5}$ but not UVC lambs. ${ }^{*} p<0.05$.

nation with surfactant therapy (34). Considering the large airway dead space of lambs (30), it is unlikely that this mechanism plays a major role in our study. Our target $V_{\mathrm{T}}$ of $7-8 \mathrm{~mL} / \mathrm{kg}$ delivers a low normal alveolar $V_{\mathrm{T}}$ providing "gentle ventilation" of preterm lambs (who have a large anatomical dead space) and was applied to both BiLevel and A- $\mathrm{C}_{5}$ groups. The striking difference between the BiLevel and A- $\mathrm{C}_{5}$ lambs in our study is the PEEP strategy. BiLevel lambs were cycling between PEEP levels of $5 \mathrm{~cm} \mathrm{H}_{2} \mathrm{O}$ and $20 \mathrm{~cm}$ $\mathrm{H}_{2} \mathrm{O}$ (mean level of PEEP in BiLevel: $10 \mathrm{~cm} \mathrm{H}_{2} \mathrm{O}$ ), whereas A- $\mathrm{C}_{5}$ group lambs were ventilated with a constant PEEP of 5 $\mathrm{cm} \mathrm{H}_{2} \mathrm{O}$. PEEP of $7 \mathrm{~cm} \mathrm{H}_{2} \mathrm{O}$ versus $4 \mathrm{~cm} \mathrm{H}_{2} \mathrm{O}$ has been associated with a larger alveolar surfactant pool in surfactanttreated preterm lambs ventilated for $7 \mathrm{~h}$ postdelivery (35). Maintaining lung volume with relatively high levels of PEEP (up to $15 \mathrm{~cm} \mathrm{H}_{2} \mathrm{O}$ ) and small pressure differences between PIP 

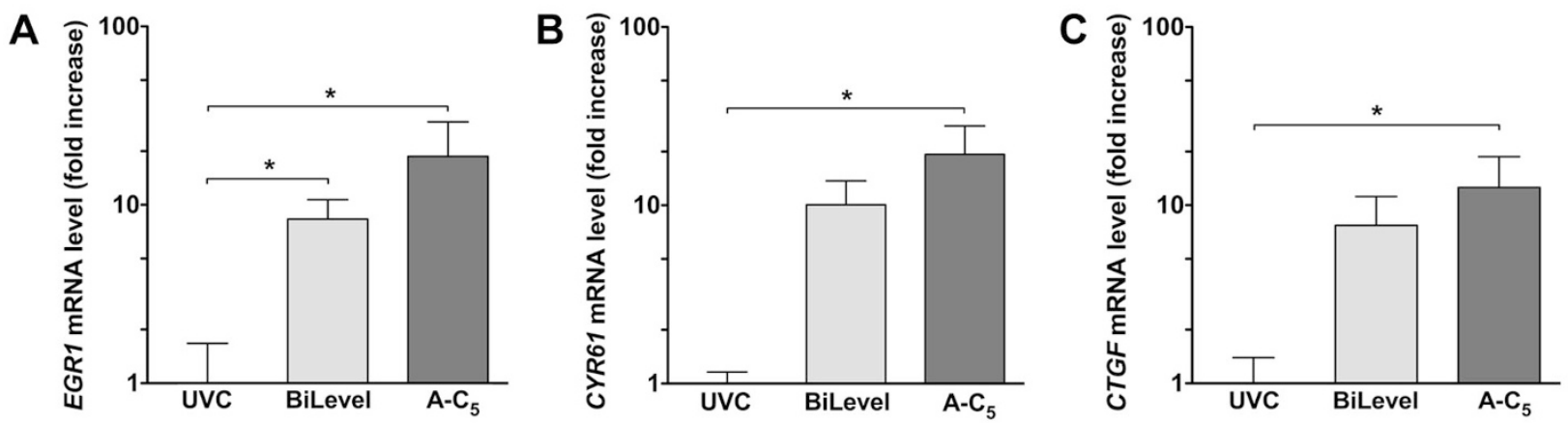

Figure 5. mRNA expression of EGR1, CYR61, and CTGF. The values for normalized mRNA expression of $A, E G R 1, B, C Y R 61$, and $C, C T G F$ in UVC, BiLevel, and $\mathrm{A}-\mathrm{C}_{5}$ lambs are shown. Fold increase in mRNA value is shown relative to UVC group. Mean (SEM) levels for each ventilation modality are expressed relative to the mean UVC value. The adjusted $p$ value indicating significance of multiple comparisons was $p=0.008 .{ }^{*} p<0.008$.

and PEEP (open-lung concept) compared with conventional ventilation had a beneficial effect on static compliance and histologic lung injury score in a term newborn piglet model $(36,37)$. Thus, it is possible that the higher level of PEEP in BiLevel compared with $\mathrm{A}-\mathrm{C}_{5}$ group lambs had a protective effect on the development of ventilator-associated lung injury.

Oxygen radical injury is a known contributor to neonatal lung injury (38). Although all ventilated lambs in this study were exposed to a constant $\mathrm{FiO}_{2}$ of 0.4 , the $\mathrm{PaO}_{2}$ in BiLevel lambs was lower than A-C group lambs during the first hour of ventilation. Because the threshold $\mathrm{PaO}_{2}$ to induce lung injury in preterm lungs is unknown (39), it cannot be excluded that the differences in $\mathrm{PaO}_{2}$ confounded the finding of reduced lung inflammatory changes in BiLevel lambs. Finally, asynchrony contributes to pulmonary morbidity in ventilated neonates (40). Although we did not formally assess breathing pattern, visual observation of the lambs and ventilator alarms did not indicate substantial asynchrony in any of the ventilation modes.

Relevance for clinical practice and further research. This is the first study to demonstrate the feasibility of endotracheal BiLevel ventilation in a preterm neonatal animal model. There were no adverse effects associated with BiLevel ventilation and gas exchange was comparable with $\mathrm{A}-\mathrm{C}_{5}$ ventilation.

Comparable $\mathrm{PaCO}_{2}$ in BiLevel versus $\mathrm{A}-\mathrm{C}_{5}$ lambs in the presence of similar $V_{\mathrm{T}}\left(\right.$ at $\left.\mathrm{PEEP}_{\mathrm{L}}\right)$, lower minute ventilation, and higher RR suggest that the higher respiratory rate in the BiLevel lambs was due to very small tidal volumes delivered during PEEP $_{\mathrm{H}}$.

The $\mathrm{PEEP}_{\mathrm{H}}$ of $20 \mathrm{~cm} \mathrm{H}_{2} \mathrm{O}$ for BiLevel lambs was selected based on our previous experience with these preterm lambs during $\mathrm{HFOV}$, in which MAPs greater than $20 \mathrm{~cm} \mathrm{H}_{2} \mathrm{O}$ were required to initially open the lung (41). The optimum $\mathrm{PEEP}_{\mathrm{H}}$ and the role of tidal volume at $\mathrm{PEEP}_{\mathrm{H}}$ remain to be investigated. Regardless, achievement of comparable $\mathrm{PaCO}_{2}$ despite lower overall minute ventilation in the BiLevel group suggests more efficient ventilation in this group. We speculate that the use of BiLevel ventilation may preserve airway patency and reduce physiologic dead space, increasing available alveolar surface area for gas exchange. The trend toward a benefit of BiLevel ventilation for reducing the severity of lung injury is promising. Because of the nature of the intervention, caregivers could not be blinded to the mode of ventilation, thus, observer bias cannot be excluded. The findings of this study need confirmation in larger trials with longer duration of ventilation, assessment of potential confounders such as oxygen toxicity, and blinding of outcome assessors. Further studies would need to include a control group of pressure support ventilation, thereby adjusting for potential benefits of pressure support - a feature that was absent in our A- $\mathrm{C}_{5}$ group. Finally, transferability of our findings to human neonates can only be addressed in clinical trials powered to consider the effect of BiLevel ventilation on respiratory outcomes in the setting of other factors contributing to nature and severity of lung injury such as prenatal corticosteroids and chorioamnionitis.

In conclusion, in a preterm lamb model of RDS, BiLevel ventilation provides gas exchange equivalent to $A-C_{5}$ ventilation. The trend toward reduced markers of ventilatorassociated lung injury using BiLevel in preterm lambs warrants further investigation of this mode as a treatment for neonatal RDS.

Acknowledgments. We acknowledge the assistance and support of Dr. Jennifer Henderson, Dr. Martin Kluckow, Mr. Scott Thompson, and Mr. Paul McWilliam in undertaking these studies.

\section{REFERENCES}

1. Rimensberger PC, Pache JC, McKerlie C, Frndova H, Cox PN 2000 Lung recruitment and lung volume maintenance: a strategy for improving oxygenation and preventing lung injury during both conventional mechanical ventilation and highfrequency oscillation. Intensive Care Med 26:745-755

2. Polglase GR, Hooper SB, Gill AW, Allison BJ, McLean CJ, Nitsos I, Pillow JJ, Kluckow M 2009 Cardiovascular and pulmonary consequences of airway recruitment in preterm lambs. J Appl Physiol 106:1347-1355

3. Zwiener U, Walter B, Kratzsch B, Bauer R 2003 Marked reduction of brainstem blood flow in artificially ventilated newborn piglets during normoxia and normocapnic hypoxia. Intensive Care Med 29:2277-2284

4. Putensen C, Rasanen J, Lopez FA 1994 Ventilation-perfusion distributions during mechanical ventilation with superimposed spontaneous breathing in canine lung injury. Am J Respir Crit Care Med 150:101-108

5. Kiehl M, Schiele C, Stenzinger W, Kienast J 1996 Volume-controlled versus biphasic positive airway pressure ventilation in leukopenic patients with severe respiratory failure. Crit Care Med 24:780-784

6. Hormann C, Baum M, Putensen C, Kleinsasser A, Benzer H 1997 Effects of spontaneous breathing with BIPAP on pulmonary gas exchange in patients with ARDS. Acta Anaesthesiol Scand Suppl 111:152-155

7. Rathgeber J, Schorn B, Falk V, Kazmaier S, Spiegel T, Burchardi H 1997 The influence of controlled mandatory ventilation (CMV), intermittent mandatory ventilation (IMV) and biphasic intermittent positive airway pressure (BIPAP) on duration of intubation and consumption of analgesics and sedatives. A prospective analysis in 596 patients following adult cardiac surgery. Eur J Anaesthesiol 14:576582 
8. Seymour CW, Frazer M, Reilly PM, Fuchs BD 2007 Airway pressure release and biphasic intermittent positive airway pressure ventilation: are they ready for prime time? J Trauma 62:1298-1309

9. Jaarsma AS, Knoester H, van Rooyen F, Bos AP 2001 Biphasic positive airway pressure ventilation $(\mathrm{PeV}+)$ in children. Crit Care 5:174-177

10. Migliori C, Motta M, Angeli A, Chirico G 2005 Nasal bilevel vs. continuous positive airway pressure in preterm infants. Pediatr Pulmonol 40:426-430

11. Jobe AH, Kramer BW, Moss TJ, Newnham JP, Ikegami M 2002 Decreased indicators of lung injury with continuous positive expiratory pressure in preterm lambs. Pediatr Res 52:387-392

12. Jobe AH, Polk D, Ikegami M, Newnham J, Sly P, Kohen R, Kelly R 1993 Lung responses to ultrasound-guided fetal treatments with corticosteroids in preterm lambs. J Appl Physiol 75:2099-2105

13. Bartlett RH, Gazzaniga AB, Toomasian J, Coran AG, Roloff D, Rucker R 1986 Extracorporeal membrane oxygenation (ECMO) in neonatal respiratory failure. 100 cases. Ann Surg 204:236-245

14. Jobe AH, Newnham JP, Willet KE, Moss TJ, Gore Ervin M, Padbury JF, Sly P, Ikegami M 2000 Endotoxin-induced lung maturation in preterm lambs is not mediated by cortisol. Am J Respir Crit Care Med 162:1656-1661

15. Jobe AH, Newnham JP, Willet KE, Sly P, Ervin MG, Bachurski C, Possmayer F, Hallman M, Ikegami M 2000 Antenatal endotoxin and glucocorticoid effects on the lungs of preterm lambs. Am J Obstet Gynecol 182:401-408

16. Wallace MJ, Probyn ME, Zahra VA, Crossley K, Cole TJ, Davis PG, Morley CJ, Hooper SB 2009 Early biomarkers and potential mediators of ventilation-induced lung injury in very preterm lambs. Respir Res 10:19

17. Kramer EL, Deutsch GH, Sartor MA, Hardie WD, Ikegami M, Korfhagen TR, Le Cras TD 2007 Perinatal increases in TGF-alpha disrupt the saccular phase of lung morphogenesis and cause remodeling: microarray analysis. Am J Physiol Lung Cell Mol Physiol 293:L314-L327

18. Dolinay T, Kaminski N, Felgendreher M, Kim HP, Reynolds P, Watkins SC, Karp D, Uhlig S, Choi AM 2006 Gene expression profiling of target genes in ventilatorinduced lung injury. Physiol Genomics 26:68-75

19. Ma SF, Grigoryev DN, Taylor AD, Nonas S, Sammani S, Ye SQ, Garcia JG 2005 Bioinformatic identification of novel early stress response genes in rodent models of lung injury. Am J Physiol Lung Cell Mol Physiol 289:L468-L477

20. Chen CM, Wang LF, Chou HC, Lang YD, Lai YP 2007 Up-regulation of connective tissue growth factor in hyperoxia-induced lung fibrosis. Pediatr Res 62:128-133

21. Kasai H, Allen JT, Mason RM, Kamimura T, Zhang Z 2005 TGF-beta1 induces human alveolar epithelial to mesenchymal cell transition (EMT). Respir Res 6:56

22. Dela Cruz RH, Banner MJ, Weldon BC 2005 Intratracheal pressure: a more accurate reflection of pulmonary airway pressure in pediatric patients with respiratory failure. Pediatr Crit Care Med 6:175-181

23. Henzler D, Dembinski R, Bensberg R, Hochhausen N, Rossaint R, Kuhlen R 2004 Ventilation with biphasic positive airway pressure in experimental lung injury. Influence of transpulmonary pressure on gas exchange and haemodynamics. Intensive Care Med 30:935-943

24. Henzler D, Pelosi P, Bensberg R, Dembinski R, Quintel M, Pielen V, Rossaint R, Kuhlen R 2006 Effects of partial ventilatory support modalities on respiratory function in severe hypoxemic lung injury. Crit Care Med 34:1738-1745

25. Yu G, Yang K, Baker AB, Young I 2006 The effect of bi-level positive airway pressure mechanical ventilation on gas exchange during general anaesthesia. $\mathrm{Br} \mathrm{J}$ Anaesth 96:522-532
26. Elrazek EA 2004 Randomized prospective crossover study of biphasic intermittent positive airway pressure ventilation (BIPAP) versus pressure support ventilation (PSV) in surgical intensive care patients. Middle East J Anaesthesiol 17:1009-1021

27. Staudinger T, Kordova H, Roggla M, Tesinsky P, Locker GJ, Laczika K, Knapp S, Frass M 1998 Comparison of oxygen cost of breathing with pressure-support ventilation and biphasic intermittent positive airway pressure ventilation. Crit Care Med 26:1518-1522

28. te Pas AB, Walther FJ 2007 A randomized, controlled trial of delivery-room respiratory management in very preterm infants. Pediatrics 120:322-329

29. Probyn ME, Hooper SB, Dargaville PA, McCallion N, Crossley K, Harding R, Morley CJ 2004 Positive end expiratory pressure during resuscitation of premature lambs rapidly improves blood gases without adversely affecting arterial pressure. Pediatr Res 56:198-204

30. Wada K, Jobe AH, Ikegami M 1997 Tidal volume effects on surfactant treatment responses with the initiation of ventilation in preterm lambs. J Appl Physiol $83: 1054-1061$

31. Vazquez de Anda GF, Hartog A, Verbrugge SJ, Gommers D, Lachmann B 1999 The open lung concept: pressure-controlled ventilation is as effective as high-frequency oscillatory ventilation in improving gas exchange and lung mechanics in surfactantdeficient animals. Intensive Care Med 25:990-996

32. Davis JM, Penney DP, Notter RH, Metlay L, Dickerson B, Shapiro DL 1989 Lung injury in the neonatal piglet caused by hyperoxia and mechanical ventilation. J App Physiol 67:1007-1012

33. Bjorklund LJ, Ingimarsson J, Curstedt T, John J, Robertson B, Werner O, Vilstrup CT 1997 Manual ventilation with a few large breaths at birth compromises the therapeutic effect of subsequent surfactant replacement in immature lambs. Pediatr Res 42:348-355

34. Ingimarsson J, Bjorklund LJ, Curstedt T, Gudmundsson S, Larsson A, Robertson B, Werner O 2004 Incomplete protection by prophylactic surfactant against the adverse effects of large lung inflations at birth in immature lambs. Intensive Care Med 30:1446-1453

35. Michna J, Jobe AH, Ikegami M 1999 Positive end-expiratory pressure preserves surfactant function in preterm lambs. Am J Respir Crit Care Med 160:634-639

36. van Kaam AH, de Jaegere A, Haitsma JJ, Van Aalderen WM, Kok JH, Lachmann B 2003 Positive pressure ventilation with the open lung concept optimizes gas exchange and reduces ventilator-induced lung injury in newborn piglets. Pediatr Res 53:245-253

37. van Kaam AH, Dik WA, Haitsma JJ, De Jaegere A, Naber BA, van Aalderen WM, Kok JH, Lachmann B 2003 Application of the open-lung concept during positivepressure ventilation reduces pulmonary inflammation in newborn piglets. Bio Neonate 83:273-280

38. Saugstad OD 1997 Bronchopulmonary dysplasia and oxidative stress: are we closer to an understanding of the pathogenesis of BPD? Acta Paediatr 86:1277-1282

39. Poets CF 1998 When do infants need additional inspired oxygen? A review of the current literature. Pediatr Pulmonol 26:424-428

40. Lipscomb AP, Thorburn RJ, Reynolds EO, Stewart AL, Blackwell RJ, Cusick G, Whitehead MD 1981 Pneumothorax and cerebral haemorrhage in preterm infants. Lancet 1:414-416

41. Pillow JJ, Sly PD, Hantos Z 2004 Monitoring of lung volume recruitment and derecruitment using oscillatory mechanics during high-frequency oscillatory ventilation in the preterm lamb. Pediatr Crit Care Med 5:172-180 